\title{
Variations in Cupressus lusitanica Mill. Seed Yield and Quality under Different Extraction Conditions in Kenya
}

\author{
Alice Adongo Onyango ${ }^{*}$, Peter Murithi Angaine, Joram Mbinga, Jesse O. Owino \\ Rift Valley Eco-region Research Program, Kenya Forestry Research Institute (KEFRI), Londiani, Kenya \\ *Corresponding Author: Alice Adongo Onyango, Rift Valley Eco-region Research Program, Kenya \\ Forestry Research Institute (KEFRI), Londiani, Kenya
}

\begin{abstract}
Seed demand for Cupressus lusitanica seed has been increasing to meet the myriad uses for the species. It is grown in Kenya majorly as a acommercial plantation species. This necessitated the need to enhance seed extraction for sustainable availability of quality seed. Therefore this study's objective was understanding the variations of $C$. lusitanica seed yield and quality under different extraction conditions. Five hundred and forty mature cones were collected and subjected to different soaking treatments (SHsoaked in hot water and SC-soaked in cold water) to mimic the current practice (NS-not soaked) and suggest ways for improvement. Seed yield performance was compared across different extraction temperatures current practice-drying bed $(\mathrm{DB})$, greenhouse $(\mathrm{GH})$ against extraction temperatures $40^{\circ} \mathrm{C}, 50^{\circ} \mathrm{C}, 65^{\circ} \mathrm{C}$, and $85^{\circ} \mathrm{C}$, within a 48 hour period. Germination tests were conducted to validate seed quality under different extraction treatments. The key finding from this study was that cones pretreated by soaking in cold water and

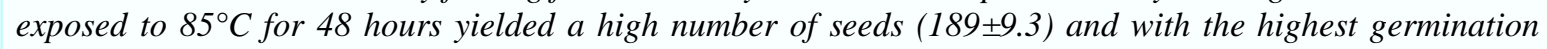
percent $(15 \%, p<0.05)$. This finding allows for the design of a low energy-intensive method using cold water and higher temperatures for a short duration for increased seed yield while maintaining quality.
\end{abstract}

Keywords: cone pretreatment, Cupressus lusitanica, extraction temperature, germination, seed yield

\section{INTRODUCTION}

Globally, Cupressus lusitanica is one of the important fast-growing plantation species, highly preferred for biomass, fuelwood, timber, and medicinal uses (1-5). In the tropics and subtropics, this species has been identified and prioritized for planting to support commercial forestry, afforestation, and conservation (6-10). In Kenya this is an exotic species planted commercially for the production of saw timber, plywood, and poles for building and construction; and for services such as live fence, shade, and ornamental (11-14). These uses have led to increasing demand for $C$. lusitanica seed for ease of propagation $(15,16)$. Seeds have been the traditional and primary source of $C$. lusitanica propagules (17-20).

In order to meet the global seed demand, $C$. lusitanica seeds are extracted from cones using myriad ways $(21,22)$. There is scanty literature focusing on cone gathering and seed harvesting practices targeting cypress, whereby, seed release and seed germination are greatly influenced by the environment (temperature and moisture) (23-25). Cypress cones sizes have been previously shown to have a positive correlation with seed yield but a gap exists in the influence of moisture and temperature on seed extraction $(23,26,27)$. Seed counting has been used conventionally as a method of quantifying seed yield in various coniferous species $(25,27-29)$. Improvement of seed extraction techniques in conifers has contributed to the changes in seed handling processes and the overall seed quality assessed by germination capacity (30-33).

The present study seeks to analyze the effects of extraction pretreatments, site conditions, and temperature on seed yield and quality of $C$. lusitanica. The specific objectives were (i) To determine the effect of soaking of cones and temperature duration on seed release, (ii) To determine the effects of extraction temperature and duration on seed release (iii) To determine the interactions between soaking pretreatments, extraction temperature and duration on seed release and (iv) To determine the interactions between soaking pretreatments, extraction temperature and duration on germination of $C$. lusitanica seeds 


\section{MATERIALS AND METHODS}

Cupressus lusitanica cones were collected from a clonal seed orchard in Londiani within the Rift Valley region of Kenya. The area is located at latitude $0^{\circ} 10^{\prime}$ South and longitude $35^{\circ} 36^{\prime} \mathrm{E}$ and also at an elevation of 2,320 to $2,500 \mathrm{~m}$ above sea level. The annual precipitation ranges from 1,000 to $1,500 \mathrm{~mm}$. The temperature ranges between $14^{\circ} \mathrm{C}$ and $17^{\circ} \mathrm{C}$ with an average of $15.7^{\circ} \mathrm{C}$. This area has a cool and moist climate, which is suitable for $C$. lusitanica seed production (34).

Mature cones were collected in June 2020, from a 14-year-old $C$. lusitanica seed orchard. The cones were closed at that time (35). The cones were packed in gunny bags and were brought to the Rift Valley Eco-region Research Programme laboratory, Kenya Forestry Research Institute (KEFRI).

Five hundred and forty cones were randomly selected as described by Aniszewska, 2013, and grouped in batches three groups of 180 each. The first group of cones not to be soaked (NS) was used as the control. The second group (180 cones) consisted of cones to be subjected to soaking in cold water (SC) while the third group (180 cones) was of cones to be subjected to soaking in hot water (SH). Further, in setting up for the temperature extraction experiment, the three groups (NS, SC, and $\mathrm{SH}$ ) of cones were subdivided into 6 temperature categories $\left(\mathrm{GH}, \mathrm{DB}, 40^{\circ} \mathrm{C}, 50^{\circ} \mathrm{C}, 65^{\circ} \mathrm{C}\right.$, and $85^{\circ} \mathrm{C}$ ) of 30 cones each then labeled (Table 1) (37). Greenhouse (GH) and seed drying bed (DB) are infrastructures currently used for seed extraction in Londiani, Kenya. The temperature and humidity during this study were recorded using a data logger. The other experimental temperatures $\left(40^{\circ} \mathrm{C}, 50^{\circ} \mathrm{C}, 65^{\circ} \mathrm{C}\right.$, and $\left.85^{\circ} \mathrm{C}\right)$ were achieved using an oven (YAMATO DS411).Coldwater soaking involved immersion of cones in a water bath for 10 minutes while soaking in hot water involved immersion of cones for 10 minutes in water that had been heated to boiling point $100^{\circ} \mathrm{C}(38)$.

Table1. Seed extraction by temperature regimes $\left(\mathrm{GH}, \mathrm{DB}, 40^{\circ} \mathrm{C}, 50^{\circ} \mathrm{C}, 65^{\circ} \mathrm{C}\right.$, and $\left.85^{\circ} \mathrm{C}\right)$, cone pretreatment $(\mathrm{NS}$, $S H \& S C)$ and the number of cones per treatment.

\begin{tabular}{|c|l|l|l|}
\hline S/No & Temperature & Treatment & No of cones \\
\hline 1. & $\mathrm{DB}\left(49 \pm 3.7^{\circ} \mathrm{C}\right)$ & NS & 30 \\
\hline 2. & & SH & 30 \\
\hline 3. & & SC & 30 \\
\hline 4. & $\mathrm{GH}\left(34.9 \pm 12.0^{\circ} \mathrm{C}\right)$ & NS & 30 \\
\hline 5. & & SH & 30 \\
\hline 6. & & SC & 30 \\
\hline 7. & $40^{\circ} \mathrm{C}$ & NS & 30 \\
\hline 8. & & SH & 30 \\
\hline 9. & & SC & 30 \\
\hline 10. & $50^{\circ} \mathrm{C}$ & NS & 30 \\
\hline 11. & & SH & 30 \\
\hline 12. & & SC & 30 \\
\hline 13. & $65^{\circ} \mathrm{C}$ & NS & 30 \\
\hline 14. & & SH & 30 \\
\hline 15. & & SC & 30 \\
\hline 16. & $85^{\circ} \mathrm{C}$ & NS & 30 \\
\hline 17. & & SH & 30 \\
\hline 18. & & SC & 30 \\
\hline Total & & 540 \\
\hline
\end{tabular}

$D B=$ Drying bed, $G H=$ Greenhouse, $N S=$ Not soaked, $S C=$ Soaked in cold water, $S H=$ soaked in hot water .

After pretreatment (NS, SH, and SC), cones were put in marked glass Petri dishes and subjected to extraction under the different conditions (DB, GH, $40^{\circ} \mathrm{C}, 50^{\circ} \mathrm{C}, 65^{\circ} \mathrm{C}, 85^{\circ} \mathrm{C}$ ) for up to 48 hours. Observations for seed release and seed counts per cone were done at 24 hours and at 48 hours. Seeds that had not been released from open cones were forcefully removed manually using forceps to account for seeds that were retained in a cone and labeled as 48F (48hours forced).

Germination tests were conducted for seed released after $24 \mathrm{hr}$ and seeds released after $48 \mathrm{hr}$ under the 6 temperature conditions $\left(\mathrm{DB}, \mathrm{GH}, 40^{\circ} \mathrm{C}, 50^{\circ} \mathrm{C}, 65^{\circ} \mathrm{C}, 85^{\circ} \mathrm{C}\right)$. Four replicates of 50 seeds each from each of the 18 categories were placed in Petri dishes lined with wet cotton wool (distilled water) and placed in the cultivation chamber (TOMY CFH-415) at $27^{\circ} \mathrm{C}$ and $70 \% \mathrm{RH}$. The number of germinated 
seeds was recorded daily for up to 30 days. Radicle emergence was taken as the criterion for germinability (39).Seed released were presented as mean counts in tabular and graphical forms by soaking conditions (NS, SC, $\mathrm{SH}$ ) and extraction temperature (DB, $\mathrm{GH}, 40^{\circ} \mathrm{C}, 50^{\circ} \mathrm{C}, 65^{\circ} \mathrm{C}, 85^{\circ} \mathrm{C}$ ). A comparison of performance in seed extraction was done statistically by probability ( $\mathrm{R}$ software) and Tukey HSD performed to determine the soaking conditions and temperature ideal for most seed yields. Germination percentage was done for different soaking and extraction temperatures to determine the treatment with the highest performance in quality $(\mathrm{p}<0.05)$.

\section{RESULTS AND DISCUSSION}

Within the first 24 hours, cones that were soaked in cold water had released up to $77 \%$ of seeds from the cone. After 48 hours this study observed that cones soaked in cold water (SC) had the highest mean number of seeds released $(278 \pm 2.7, \mathrm{p}<0.05)$ accounting for $90 \%$ of the seed in a cone with only $10 \%$ retained in the cone. The current practice of $C$. lusitanica seed extraction without soaking the cones yields $61 \%(55 \pm 2.1, \mathrm{p}<0.05)$ with $39 \%$ being retained in the cone after 48 hours (Table 2$)$. In this study, soaking of the cones and extracting seeds after 48 hours showed an increased yield of $90 \%$ $(229 \pm 2.2, \mathrm{p}<0.05)$. The mean number of seeds released from the 540 cones after the soaking treatment was $171 \pm 2.1(\mathrm{p}<0.05)$ and the mean number of seeds retained in a cone was $29 \pm 1.2(\mathrm{p}<0.05)$ (Table 2).Studies on cypress cone processing have focused on soaking and non-soaking practices. The key observation in regard to the soaking effect was that soaking in cold water (SC) in this study, had a higher seed yield than cones that were not soaked $(18,40,41)$. This finding refined Belcher and Karrfalt, (1977) study whose observations on cypress cone opening suggested 10 seconds soaking in hot water and soaking in cool water improved seed yield by $20-50 \%$ without specifying the exposure. This study showed that the combined effect of soaking cypress cones $(\mathrm{SC}+\mathrm{SH})$, prior to extraction resulted in $90 \%$ seed yield compared to the current practice of not soaking (NS) which yielded 61\% (Table 2).Soaking has been shown to have an effect on the serotiny of cypress cones and the retention of seeds (41). This study observed that the cones that were not soaked (NS) retained the highest number of seeds after 48 hours (39\%) that had to be forced out. This study, therefore, agrees that soaking had a positive effect on seed release from $C$. lusitanica cones. Thus, soaking as a pretreatment reduces the extraction time while maintaining a higher seed yield.

Table2. Mean seed counts after exposure 24 hours, 48 hours, and forcing after 48 hours (48F), from each treatment (NS-not soaked, SH-soaked in hot water and SC-soaked in cold water) with standard error, and percent of total seed released by exposure and cumulative percent of seed released at the end of 48 hours including the forced out seeds.

\begin{tabular}{|l|l|l|l|l|l|}
\hline $\begin{array}{l}\text { Treatme } \\
\text { nt }\end{array}$ & $\begin{array}{l}\text { Duration } \\
\text { hrs) }\end{array}$ & $\begin{array}{l}\text { Mean cumulative number of } \\
\text { Seeds }\end{array}$ & SE & $\begin{array}{l}\text { Percent of seed } \\
\text { released (\%) }\end{array}$ & $\begin{array}{l}\text { Percent of cumulative seed } \\
\text { released (\%) }\end{array}$ \\
\hline NS & 24 & 19 & 1.7 & 21 & \\
\hline SH & 24 & 136 & 2.0 & 67 & \\
\hline SC & 24 & 236 & 2.5 & 77 & 61 \\
\hline NS & 48 & 55 & 2.1 & 39 & 90 \\
\hline SH & 48 & 180 & 1.6 & 22 & 90 \\
\hline SC & 48 & 278 & 2.7 & 14 & 39 \\
\hline NS & $48 \mathrm{~F}$ & 91 & 1.1 & 39 & 10 \\
\hline SH & $48 \mathrm{~F}$ & 201 & 0.9 & 10 & 10 \\
\hline SC & $48 \mathrm{~F}$ & 307 & 1.5 & 10 & $100 \%$ \\
\hline
\end{tabular}

The totals for each treatment (NS, SH, and SC) in the percent columns $=100 \%$ per treatment per column $(n=540)$

This study observed that the lower temperature for extraction (DB, $\mathrm{GH}$, and $40^{\circ} \mathrm{C}$ ) yielded $58 \%$ of seed at the end of 24 hours. The higher extraction temperatures $\left(50^{\circ} \mathrm{C}, 65^{\circ} \mathrm{C}\right.$, and $\left.85^{\circ} \mathrm{C}\right)$ had the highest mean cumulative seed yield of $153 \pm 10.1,149 \pm 10.6$ and $145 \pm 9.6$ respectively at 24 hours. This accounted for $71 \%$ and $73 \%$ of the available seed from the cone (Table 3). After 48 hours the same higher extraction temperatures maintained the highest cumulative seed yield of $202 \pm 10.2,192 \pm 10.6$, and $189 \pm 9.3$ accounting for $93 \%$ and $95 \%$ of the available seed from the cones. The seeds that were retained and had to be forced out from the cones ranged from 5\% to $27 \%$ for all the temperature treatments. The lower extraction temperatures $\left(\mathrm{DB}, \mathrm{GH}\right.$, and $\left.40^{\circ} \mathrm{C}\right)$ showed above $23 \%$ seed retention after 48 hours (Table 3 ).Higher temperatures have been shown to have an effect on serotiny of cypress cones and the retention of seeds though lacking information on exact temperatures preferred $(41,42)$. 
Variations in Cupressus Lusitanica Mill Seed Yield and Quality under Different Extraction Conditions in Kenya

Table3. Mean seed counts after exposure 24 hours, 48 hours and forcing after 48 hours (48F), from each temperature treatment (DB-Drying bed, GH-Green house, $40^{\circ} \mathrm{C}, 50^{\circ} \mathrm{C}, 65^{\circ} \mathrm{C}$, and $85^{\circ} \mathrm{C}$ ) with standard error, and percent of total seed released by exposure and cumulative percent of seed released at the end of 48 hours including the forced out seeds.

\begin{tabular}{|l|l|l|l|l|l|}
\hline $\begin{array}{l}\text { Treatm } \\
\text { ent }\end{array}$ & $\begin{array}{l}\text { Duration } \\
(\mathrm{hrs})\end{array}$ & $\begin{array}{l}\text { Mean cumulative number } \\
\text { of seeds }\end{array}$ & SE & $\begin{array}{l}\text { Percent of seed } \\
\text { released (\%) }\end{array}$ & $\begin{array}{l}\text { Percent of cumulative } \\
\text { seed released (\%) }\end{array}$ \\
\hline $\mathrm{DB}$ & 24 & 103 & 8.8 & 58 & \\
\hline $\mathrm{GH}$ & 24 & 120 & 9.7 & 58 & \\
\hline $40^{\circ} \mathrm{C}$ & 24 & 111 & 8.6 & 58 & \\
\hline $50^{\circ} \mathrm{C}$ & 24 & 153 & 10.1 & 71 & \\
\hline $65^{\circ} \mathrm{C}$ & 24 & 149 & 10.6 & 73 & \\
\hline $85^{\circ} \mathrm{C}$ & 24 & 145 & 9.6 & 73 & 73 \\
\hline $\mathrm{DB}$ & 48 & 130 & 9.2 & 15 & 77 \\
\hline $\mathrm{GH}$ & 48 & 159 & 9.5 & 19 & 81 \\
\hline $40^{\circ} \mathrm{C}$ & 48 & 155 & 9.7 & 23 & 93 \\
\hline $50^{\circ} \mathrm{C}$ & 48 & 202 & 10.2 & 22 & 93 \\
\hline $65^{\circ} \mathrm{C}$ & 48 & 192 & 10.6 & 21 & 95 \\
\hline $85^{\circ} \mathrm{C}$ & 48 & 189 & 9.3 & 22 & 27 \\
\hline $\mathrm{DB}$ & $48 \mathrm{~F}$ & 179 & 9.0 & 27 & 23 \\
\hline $\mathrm{GH}$ & $48 \mathrm{~F}$ & 206 & 8.7 & 23 & 19 \\
\hline $40^{\circ} \mathrm{C}$ & $48 \mathrm{~F}$ & 191 & 9.5 & 19 & 7 \\
\hline $50^{\circ} \mathrm{C}$ & $48 \mathrm{~F}$ & 218 & 10.0 & 7 & 7 \\
\hline $65^{\circ} \mathrm{C}$ & $48 \mathrm{~F}$ & 206 & 10.0 & 7 & 5 \\
\hline $85^{\circ} \mathrm{C}$ & $48 \mathrm{~F}$ & 199 & 9.2 & 5 & \\
\hline
\end{tabular}

The totals for each temperature treatment $\left(\mathrm{DB}, \mathrm{GH}, 40^{\circ} \mathrm{C}, 50^{\circ} \mathrm{C}, 65^{\circ} \mathrm{C}\right.$, and $\left.85^{\circ} \mathrm{C}\right)$ and exposure $(24 \mathrm{hrs}, 48 \mathrm{hre}$, and $48 \mathrm{~F}$ in the percent columns $=100 \%$ per treatment per column $(n=540)$

This study similarly observed that higher temperatures $\left(50^{\circ} \mathrm{C}, 65^{\circ} \mathrm{C}\right.$, and $\left.85^{\circ} \mathrm{C}\right)$ resulted in the highest seed yield at both 24 and 48 hours of exposure. The same higher temperatures caused the cones to only retain $5 \%$ to $7 \%$ of seed that had to be forced out after 48 hours. The present study observed no significant differences $(\mathrm{P}<0.05)$ in seed yield extracted at $50^{\circ} \mathrm{C}, 65^{\circ} \mathrm{C}$, and $85^{\circ} \mathrm{C}$ for the C. lusitanica cones. Observations from this study showed that for the higher temperatures, the first 24 hours had significantly higher seed yield than the next 24 hours ( 48 hours) which agreed with other studies $(37,43)$.

The cones that were not soaked prior to extraction (NS) and subjected to lower extraction temperatures (DB, $\mathrm{GH}$, and $40^{\circ} \mathrm{C}$ ) yielded between 0 to 9 mean cumulative seed released after 24 hours (Table 4). The highest performing cones at 24 hours came from cones subjected to $50^{\circ} \mathrm{C}$ and $65^{\circ} \mathrm{C}$ after being soaked in cold water (SC) that yielded $264 \pm 4.4$ and $269 \pm 5.2$ respectively. These temperatures of $50^{\circ} \mathrm{C}$ and $65^{\circ} \mathrm{C}$ similarly performed best on cumulative seed released after 48 hours; $317 \pm 1.3$ and $316 \pm 0.2$ respectively, $(\mathrm{p}<0.05)$. Cones that were soaked in cold water and exposed to $65^{\circ} \mathrm{C}$ had released $98.2 \%$ of the available seed in the cone (Table 4). In relation to seed retention in the cones, the lower extraction temperatures yielded a high variability ranging from $11.4 \%$ to $75.5 \%$, contrasting with the lower variability of $1.8 \%$ to $21.4 \%$ observed in the higher extraction temperatures $\left(50^{\circ} \mathrm{C}, 65^{\circ} \mathrm{C}\right.$, and $\left.85^{\circ} \mathrm{C}\right)$ (Table 4).There are studies that have shown a combination of environmental factors could lead to increased seed yield from cypress cones $(37,43)$. This study showed that the combined effect of soaking $C$. lusitanica cones in cold water and exposing it to a high temperature of $65^{\circ} \mathrm{C}$ for 48 hours yielded $98 \%$ of the seeds in a cone, refining the environmental factors required to attain this yield. This is important to seed production and designing the mechanism for this production to be achieved. 
Variations in Cupressus Lusitanica Mill Seed Yield and Quality under Different Extraction Conditions in Kenya

Table4. Mean seed counts after treatment (NS-not soaked, SH-soaked in hot water and SC-soaked in cold water), each temperature treatment (DB-Drying bed, GH-Glass house, $40^{\circ} \mathrm{C}, 50^{\circ} \mathrm{C}, 65^{\circ} \mathrm{C}$, and $\left.85^{\circ} \mathrm{C}\right)$, and exposure 24 hours, 48 hours and forcing after 48 hours $(48 F)$, with standard error, and percent of total seed released by treatment, by temperature, by exposure and cumulative percent of seed released at the end of 48 hours including the forced out seeds.

\begin{tabular}{|c|c|c|c|c|c|c|}
\hline $\begin{array}{l}\text { Treat } \\
\text { ment }\end{array}$ & $\begin{array}{r}\text { Temper } \\
\text { ature }\end{array}$ & $\begin{array}{l}\text { Duration } \\
\text { (hrs) }\end{array}$ & $\begin{array}{l}\text { Cumulative } \\
\text { number of seed }\end{array}$ & SE & $\begin{array}{r}\text { Percent number of } \\
\text { seed released }(\%)\end{array}$ & $\begin{array}{r}\text { Percent cumulative number of } \\
\text { seed released }(\%)\end{array}$ \\
\hline NS & $\mathrm{DB}$ & 24 & 0 & 0.1 & 0.6 & \\
\hline SH & DB & 24 & 106 & 0.7 & 56.5 & \\
\hline $\mathrm{SC}$ & DB & 24 & 204 & 0.1 & 73.2 & \\
\hline NS & $\mathrm{GH}$ & 24 & 0 & 0.0 & 0.1 & \\
\hline $\mathrm{SH}$ & $\mathrm{GH}$ & 24 & 138 & 2.6 & 64.7 & \\
\hline $\mathrm{SC}$ & $\mathrm{GH}$ & 24 & 221 & 0.0 & 73.1 & \\
\hline NS & $40^{\circ} \mathrm{C}$ & 24 & 9 & 0.6 & 10.8 & \\
\hline $\mathrm{SH}$ & $40^{\circ} \mathrm{C}$ & 24 & 119 & 2.9 & 63.6 & \\
\hline $\mathrm{SC}$ & $40^{\circ} \mathrm{C}$ & 24 & 205 & 1.1 & 67.6 & \\
\hline NS & $50^{\circ} \mathrm{C}$ & 24 & 37 & 3.9 & 36.0 & \\
\hline $\mathrm{SH}$ & $50^{\circ} \mathrm{C}$ & 24 & 159 & 5.0 & 73.7 & \\
\hline $\mathrm{SC}$ & $50^{\circ} \mathrm{C}$ & 24 & 264 & 4.4 & 79.2 & \\
\hline NS & $65^{\circ} \mathrm{C}$ & 24 & 32 & 3.5 & 35.3 & \\
\hline $\mathrm{SH}$ & $65^{\circ} \mathrm{C}$ & 24 & 148 & 4.5 & 72.1 & \\
\hline $\mathrm{SC}$ & $65^{\circ} \mathrm{C}$ & 24 & 269 & 5.2 & 83.5 & \\
\hline NS & $85^{\circ} \mathrm{C}$ & 24 & 38 & 4.3 & 41.3 & \\
\hline $\mathrm{SH}$ & $85^{\circ} \mathrm{C}$ & 24 & 145 & 5.0 & 72.7 & \\
\hline $\mathrm{SC}$ & $85^{\circ} \mathrm{C}$ & 24 & 252 & 5.0 & 82.8 & \\
\hline NS & DB & 48 & 18 & 2.0 & 24.0 & 24.5 \\
\hline $\mathrm{SH}$ & DB & 48 & 146 & 3.1 & 21.4 & 77.9 \\
\hline $\mathrm{SC}$ & DB & 48 & 227 & 2.4 & 8.3 & 81.5 \\
\hline NS & $\mathrm{GH}$ & 48 & 42 & 5.0 & 40.5 & 40.6 \\
\hline $\mathrm{SH}$ & $\mathrm{GH}$ & 48 & 182 & 2.1 & 20.6 & 85.3 \\
\hline $\mathrm{SC}$ & $\mathrm{GH}$ & 48 & 253 & 3.1 & 10.6 & 83.8 \\
\hline NS & $40^{\circ} \mathrm{C}$ & 48 & 40 & 3.2 & 36.9 & 47.7 \\
\hline $\mathrm{SH}$ & $40^{\circ} \mathrm{C}$ & 48 & 166 & 1.5 & 25.0 & 88.6 \\
\hline $\mathrm{SC}$ & $40^{\circ} \mathrm{C}$ & 48 & 259 & 4.3 & 18.0 & 85.6 \\
\hline NS & $50^{\circ} \mathrm{C}$ & 48 & 81 & 1.0 & 42.6 & 78.6 \\
\hline $\mathrm{SH}$ & $50^{\circ} \mathrm{C}$ & 48 & 207 & 0.2 & 22.2 & 95.8 \\
\hline $\mathrm{SC}$ & $50^{\circ} \mathrm{C}$ & 48 & 317 & 1.3 & 15.8 & 95.0 \\
\hline NS & $65^{\circ} \mathrm{C}$ & 48 & 71 & 0.6 & 42.4 & 77.7 \\
\hline $\mathrm{SH}$ & $65^{\circ} \mathrm{C}$ & 48 & 190 & 0.3 & 20.5 & 92.6 \\
\hline $\mathrm{SC}$ & $65^{\circ} \mathrm{C}$ & 48 & 316 & 0.2 & 14.8 & 98.2 \\
\hline NS & $85^{\circ} \mathrm{C}$ & 48 & 81 & 0.0 & 46.0 & 87.3 \\
\hline $\mathrm{SH}$ & $85^{\circ} \mathrm{C}$ & 48 & 192 & 0.1 & 23.6 & 96.3 \\
\hline $\mathrm{SC}$ & $85^{\circ} \mathrm{C}$ & 48 & 295 & 0.2 & 14.1 & 96.8 \\
\hline NS & DB & $48 \mathrm{~F}$ & 73 & 3.3 & 75.5 & 75.5 \\
\hline $\mathrm{SH}$ & DB & $48 \mathrm{~F}$ & 187 & 1.6 & 22.1 & 22.1 \\
\hline $\mathrm{SC}$ & DB & $48 \mathrm{~F}$ & 278 & 3.0 & 18.5 & 18.5 \\
\hline NS & $\mathrm{GH}$ & $48 \mathrm{~F}$ & 102 & 1.4 & 59.4 & 59.4 \\
\hline $\mathrm{SH}$ & GH & $48 \mathrm{~F}$ & 213 & 1.1 & 14.7 & 14.7 \\
\hline $\mathrm{SC}$ & GH & $48 \mathrm{~F}$ & 302 & 2.6 & 16.2 & 16.2 \\
\hline NS & $40^{\circ} \mathrm{C}$ & $48 \mathrm{~F}$ & 84 & 1.5 & 52.3 & 52.3 \\
\hline $\mathrm{SH}$ & $40^{\circ} \mathrm{C}$ & $48 \mathrm{~F}$ & 188 & 1.0 & 11.4 & 11.4 \\
\hline $\mathrm{SC}$ & $40^{\circ} \mathrm{C}$ & $48 \mathrm{~F}$ & 303 & 1.3 & 14.4 & 14.4 \\
\hline NS & $50^{\circ} \mathrm{C}$ & $48 \mathrm{~F}$ & 103 & 1.1 & 21.4 & 21.4 \\
\hline
\end{tabular}


Variations in Cupressus Lusitanica Mill Seed Yield and Quality under Different Extraction Conditions in Kenya

\begin{tabular}{|r|r|r|r|r|r|r|}
\hline $\mathrm{SH}$ & $50^{\circ} \mathrm{C}$ & $48 \mathrm{~F}$ & 216 & 0.7 & 4.2 & 4.2 \\
\hline $\mathrm{SC}$ & $50^{\circ} \mathrm{C}$ & $48 \mathrm{~F}$ & 333 & 0.8 & 5.0 & 5.0 \\
\hline $\mathrm{NS}$ & $65^{\circ} \mathrm{C}$ & $48 \mathrm{~F}$ & 91 & 1.5 & 22.3 & 22.3 \\
\hline $\mathrm{SH}$ & $65^{\circ} \mathrm{C}$ & $48 \mathrm{~F}$ & 205 & 1.1 & 7.4 & 7.4 \\
\hline $\mathrm{SC}$ & $65^{\circ} \mathrm{C}$ & $48 \mathrm{~F}$ & 322 & 0.6 & 1.8 & 1.8 \\
\hline $\mathrm{NS}$ & $85^{\circ} \mathrm{C}$ & $48 \mathrm{~F}$ & 92 & 1.1 & 12.7 & 3.7 \\
\hline $\mathrm{SH}$ & $85^{\circ} \mathrm{C}$ & $48 \mathrm{~F}$ & 199 & 0.5 & 3.7 & 3.7 \\
\hline $\mathrm{SC}$ & $85^{\circ} \mathrm{C}$ & $48 \mathrm{~F}$ & 304 & 0.9 & 3.2 \\
\hline
\end{tabular}

The totals for each treatment (NS, SH, and $\mathrm{SC}$ ), temperature $\left(\mathrm{DB}, \mathrm{GH}, 40^{\circ} \mathrm{C}, 50^{\circ} \mathrm{C}, 65^{\circ} \mathrm{C}\right.$, and $\left.85^{\circ} \mathrm{C}\right)$ and extraction period ( 24 hours, 48 hours and $48 F$ ) in the percent columns $=100 \%$ per treatment per temperature per column $(n=540)$.

Assessment of germination performance over a period of 30 days showed that seeds extracted from cones that were soaked in hot water $(\mathrm{SH})$ had the lowest cumulative germination percentage (Figure 1a). Germination performance ranged between 0 to $15 \%$ for soaking and extraction temperature interaction. The differences were observed in seeds that were extracted after 48 hours subjected to $85 \mathrm{C}$ for cones that were soaked in cold water (SC) prior to extraction $(>15 \%, \mathrm{p}<0.05)$. The worst performing were seeds extracted from cones subjected to soaking in hot water (SH) whether exposed for 24 or 48 hours (Figure 1b). This study observed similar germination performance of seeds from cones that were not soaked as compared to Sfairi et al, (2012) study who observed germination performance of $<20 \%$ to about $40 \%$. The present study noted that $C$. lusitanica seeds from cones that were soaked in hot water before extraction performed poorly (Figure 1a). Many studies have focused on the effect of other soaking media on seed germination, while the present study focused on the soaking of cones in cold and hot water, and their effect on germination (45-47). Studies have shown that the seed derived from seed processing can be no better than the speed with which you start $(27,40,44,46,48,49)$. The same studies have shown that to upgrade seed quality substantially, it would be at the expense of decreasing the seed volume by removing the empty and damaged seed for which this study did not do. Hence, the germination performance in this study varied from 0 to $15 \%$. This study observed that seeds extracted from cones soaked in cold water and extracted after 48 hours at $85^{\circ} \mathrm{C}$ had the highest germination performance (Figure $1 \mathrm{~b}$ ).

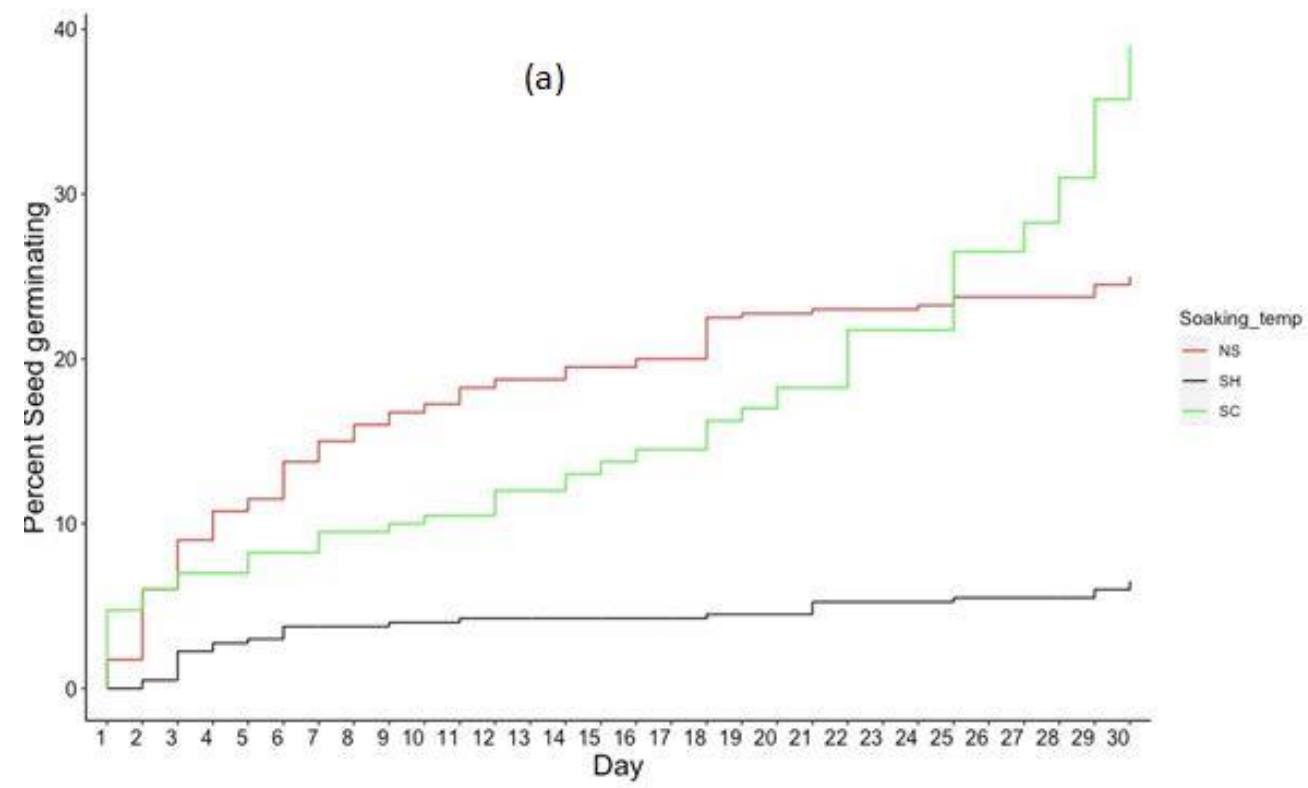




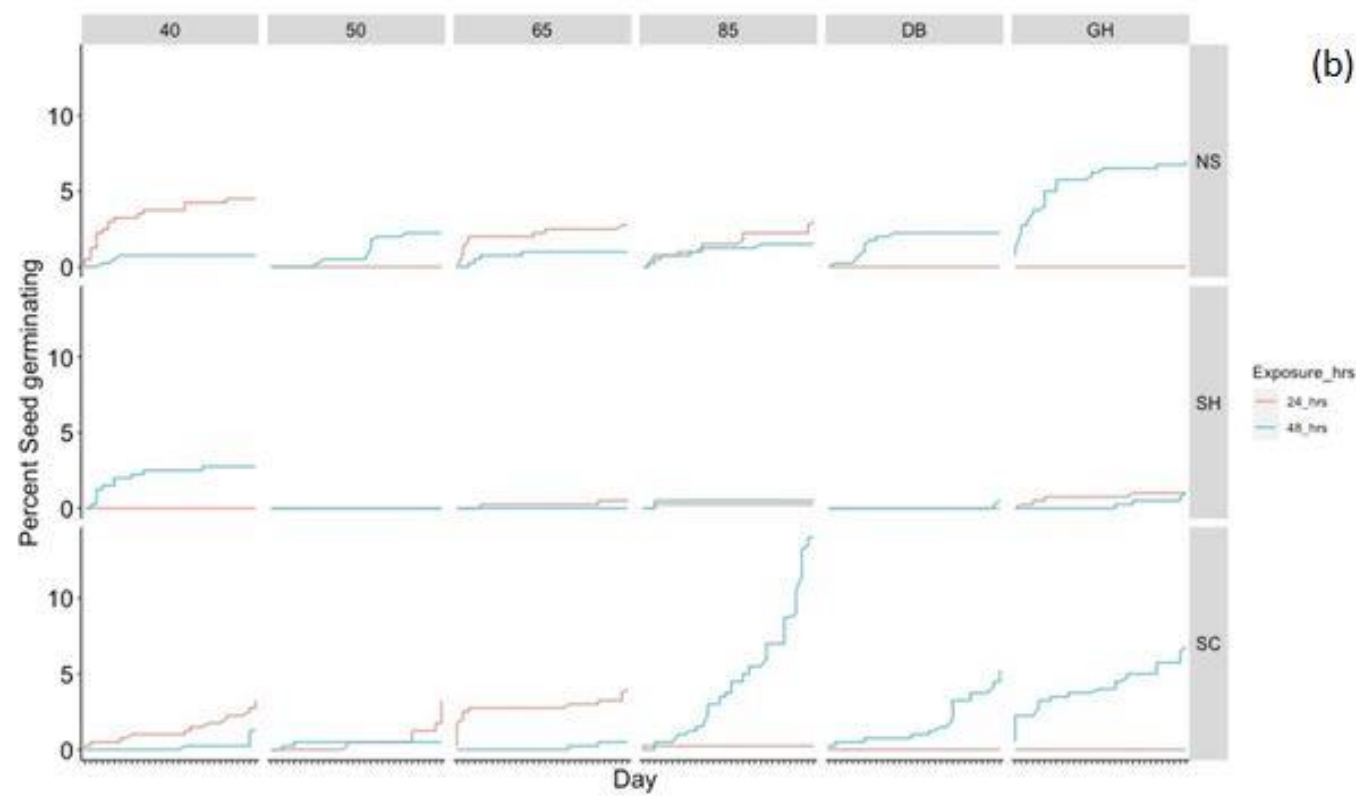

Figure1. a) shows a 30-day cumulative percent germination performance based on soaking treatment (NS-not soaked-red, SH-soaked in hot water-black, and SC-soaked in cold water-green), b) shows a 30-day cumulative percent germination performance for the combined interaction of soaking (NS, SH, and SC), extraction temperature (DB-Drying bed, GH-Glass house, $40^{\circ} \mathrm{C}, 50^{\circ} \mathrm{C}, 65^{\circ} \mathrm{C}$, and $\left.85^{\circ} \mathrm{C}\right)$, and exposure period of seeds released at 24(red) and 48 hours (blue) intervals.

\section{CONClusions}

This study has shown that soaking C. lusitanicacones in cold water prior to extraction has a positive effect on seed release. Higher extraction temperatures also favor seed release both independently and combined with the soaking effect. This study has shown that the seeds extracted via a combination of soaking of $C$. lusitanica cones and extracting at a temperature of $85^{\circ} \mathrm{C}$ for 48 hours have the highest germination performance.

\section{ACKNOWLEDGMENTS}

The authors acknowledge the technicians in the Rift Valley Eco-region Research Programme of the Kenya Forestry Research Institute, for assistance during the data collection and experimental phase for this study.

\section{REFERENCES}

[1] Lemenih M, Olsson M, Karltun E. Comparison of soil attributes under Cupressus lusitanica and Eucalyptus saligna established on abandoned farmlands with continuously cropped farmlands and natural forest in Ethiopia. Forest Ecology and Management. 2004;195(1-2):57-67.

[2] Ridder RM. Global Forest Resources Assessment 2010: Options and Recommendations for a Global Remote Sensing Survey of Forests. 2007;68.

[3] Rivera-Tenorio M, Moya R, Navarro-Mora Á. Wooden trusses using metal plate connections and fabricated with Gmelina arborea, Tectona grandis and Cupressus lusitanica timber from forest plantations. Journal of the Indian Academy of Wood Science [Internet]. 2020 Dec 17;17(2):183-94. Available from: http://link.springer.com/10.1007/s13196-020-00271-z

[4] Vivian MA, Nunes GC, Dobner Jr. M, Modes KS, Grosskopf ÉJ, Belini UL. Natural durability of Cupressus lusitanica, Cryptomeria japonica and Pinus taeda woods in field trial. FLORESTA [Internet]. $2020 \mathrm{Jul}$ 10;50(3):1603. Available from: https://revistas.ufpr.br/floresta/article/view/65059

[5] Stephan J, Bercachy C, Bechara J, Charbel E, Lopez-Tirado J. Local ecological niche modelling to provide suitability maps for 27 forest tree species in edge conditions. iForest - Biogeosciences and Forestry [Internet]. 2017;13:230-7. Available from: https://iforest.sisef.org/pdf/?id=ifor3331-013

[6] Kindt R, Dawson IK, Muchugi A, Pedercini F, Roshetko JM, Noordwijk M Van, et al. The one hundred tree species prioritized for planting in the tropics and subtropics as indicated by database mining [Internet]. Nairobi, Kenya; 2021. Report No.: 312. Available from: http://dx.doi.org/10.5716/WP21001.PDF 
[7] Msanga HP, Masunga EW, Andrew SM, Fandey FH. Challenges of producing quality tree seeds to support afforestation in Tanzania. In: 1st TAFORI Scientific Conference on Forestry Research for Sustainable Industrial Economy in Tanzania [Internet]. Dodoma: TAFORI; 2018. p. 63-72. Available from: http://suaire.suanet.ac.tz/bitstream/handle/123456789/2778/Samora.pdf?sequence=1\&isAllowed=y

[8] Ayari A, Moya D, Rejeb MN, Ben Mansoura A, Albouchi A, De Las Heras J, et al. Geographical variation on cone and seed production of natural Pinus halepensis Mill. forests in Tunisia. Journal of Arid Environments [Internet]. 2011;75(5):403-10. Available from: http://dx.doi.org/10.1016/j.jaridenv. 2011.01.001

[9] Gaitán-alvarez J, Moya R, Rodríguez-zúñiga A. Characterization of Torrefied Biomass of Five Reforestation Species (Cupressus lusitanica, Dipteryx panamensis, Gmelina arborea, Tectona grandis, and Vochysia ferruginea) in Costa Rica. BioResorces. 2017;12:7566-89.

[10] Legesse A, Negash M. Species diversity, composition, structure and management in agroforestry systems: the case of Kachabira district, Southern Ethiopia. Heliyon [Internet]. 2021;7(3):e06477. Available from: https://doi.org/10.1016/j.heliyon.2021.e06477

[11] Kuria NC, Balozi KB, Kipkore W. Growth and Yield Models for Plantation-Grown Cupressus lusitanica for Central Kenya. African Journal of Education, Science and Technology [Internet]. 2019;5(2)(2):34-58. Available from: http://ajest.info/index.php/ajest/article/view/351

[12] Kenya Forest Service. Economic Potential of Popular Commercial Tree Species in Kenya [Internet]. 2020. p. 2-3. Available from: http://www.kenyaforestservice.org/documents/Brochure commercial forestry.pdf 2.pdf

[13] Trivellini G, Lindon A. Evaluation of natural resource of conservation and tourism interest in Northern Mau (Kiptunga) Forest. Research gate. 2014.

[14] Hosseini Z, Naghavi H, Latifi H, Bakhtiari SB. Estimating biomass and carbon sequestration of plantations around industrial areas using very high resolution stereo satellite imagery. iForest - Biogeosciences and Forestry [Internet]. 2019;12(6):533-41. Available from: https://iforest.sisef.org/pdf/?id=ifor3155-012

[15] Zhang Y, Hu P, Zhong C, Wei Y, Meng J, Li Z, et al. Analyses of genetic diversity, differentiation and geographic origin of natural provenances and land races of Casuarina equisetifolia based on EST-SSR markers. Forests [Internet]. 2020 Apr 10;11(4):432. Available from: www.mdpi.com/journal/forests

[16] Hansen SM, Gunnell J, Whaley A, Dai X, Harding C, Black BL. Adaptability of tree species as windbreaks for urban farms in the U.S. Intermountain West. Horticulturae [Internet]. 2020 Mar 6;6(1):17. Available from: www.mdpi.com/journal/horticulturae

[17] Maid M, Kitingan C, Kodoh J. Managing Planting Materials and Planting Stock Production of Tropical Tree Species. In: Liew KC, editor. Prospects and Utilization of Tropical Plantation Trees [Internet]. 1st ed. Boca Raton: CRC Press; 2019. p. 42-65. Available from: https:/www.taylorfrancis.com/chapters/ edit/10.1201/9780429442773-2/managing-planting-materials-planting-stock-production-tropical-treespecies-mandy-maid-crispin-kitingan-julius-kodoh

[18] Bonner FT, Vozzo JA, Elam WW, S. B. Land J. Tree seed technology training course: Instructors manual [Internet]. Vol. SO-106, General Technical Report. Louisiana; 1994. Available from: https://books.googleusercontent.com/books/content?req=AKW5QaeI_aK-QWjNH-X7yJAm959oJ FRxI SiNwybooqlAzsFB475v1hvgi8OfuYnnX13x7M41BgB4LORbgLbd6DJwoJqHwDS61BI76Uc_lbPNcz5AP k1tVKEWaThlrnnRmNh-QXifOAIPgB9SmWcqzEK_7ZJyUXQEQ84mREoMVdQuqlEY7VUG 8Wg5y QwqPErBVyOorl1

[19] Anbarashan M, Padmavathy A, Alexandar R, Dhatchanamoorhty N. Survival, growth, aboveground biomass, and carbon sequestration of mono and mixed native tree species plantations on the Coromandel Coast of India. Geology, Ecology and Landscapes [Internet]. 2019 [cited 2021 May 27];4(2):111-20. Available from: https://doi.org/10.1080/24749508.2019.1600910

[20] Albrecht J. Tree seed handbook of Kenya. Nairobi, Kenya: GTZ Forestry Seed Centre Muguga. [Internet]. 2nd ed. Omondi W, Maua JO, Gachathi FN, editors. Nairobi: Kenya Forestry Research Institute; 1993. Available from: https://www.worldcat.org/title/tree-seed-handbook-of-kenya/oclc/38979878

[21] Hofmann T, Albert L, Bocz B, Bocz D, Visi-Rajczi E. Coniferous Cones as a Forestry Waste Biomass-A Source of Antioxidants. Environmental Sciences Proceedings. 2020;3(1):82.

[22] Valette M, Vinceti B, Gregorio N, Bailey A, Thomas E, Jalonen R. Beyond fixes that fail: Identifying sustainable improvements to tree seed supply and farmer participation in forest and landscape restoration. Ecology and Society. 2020;25(4):1-26.

[23] De Magistris AA, Hashimoto PN, Masoni SL, Chiesa A. Germination of serotinous cone seeds in Cupressus ssp. Israel Journal of Plant Sciences. 2001;49(4):253-8. 
[24] Onyango AA, Angaine PM, Inoti SK, Owino JO. Patula pine (Pinus patula) cone opening under different treatments for rapid seed extraction in Londiani, Kenya. Journal of Horticulture and Forestry. 2020;12(June):63-9.

[25] Aniszewska M. A method for seed extraction process in the common pine ( Pinus sylvestris L .) subjected to mechanical processing by removal of stem. 2012;59(59):107-13.

[26] Faulkner S, Toliver J. Genetic variation of cones, seeds, and nursery-grown seedlings of baldcypress (Taxodium distichum (L.) Rich) provenances. Proceddings of 17th Southern Forest Tree Improvement Conference. 1983;1980:281-8.

[27] Angaine PM, Onyango AA, Ndungú SM, Inoti SK, Owino JO. Influence of Cupressus lusitanica Mill. cones and seed characterization on germination in Kenya. Journal of Forests. 2021;8(2):123-30.

[28] Tattoni C, Chianucci F, Ciolli M, Ferrara C, Marchino L, Zanni M, et al. A comparison of ground-based count methods for quantifying seed production in temperate broadleaved tree species. Annals of Forest Science [Internet]. 2021;78(1). Available from: https://doi.org/10.1007/s13595-020-01018-z

[29] Stoehr MU. Seed production of western larch in seed-tree systems in the southern interior of British Columbia. Forest Ecology and Management. 2000;130(1-3):7-15.

[30] Habrouk A, Retana J, Espelta JM. Role of Heat Tolerance and Cone Protection of Seeds in the Response of Three Pine Species to Wildfires. Plant ecology. 1999;145(1):91-9.

[31] Ghildiyal S, Sharma C, Gairola S. Effect of temperature on cone bursting, seed extraction and germination in five provenances of Pinus roxburghii from Garhwal Himalaya in India. Southern Forests: a Journal of Forest Science [Internet]. 2008 Jul;70(1):1-5. Available from: http://www.tandfonline.com/doi/abs/ 10.2989/SOUTH.FOR.2008.70.1.1.511

[32] Aniszewska M. Analysis of opening cones of selected coniferous trees. In: Annals of WULS, Forestry and Wood Technology [Internet]. 2010. p. 57-64. Available from: http://annals-wuls.sggw.pl/files/files/ afe2010no55full.pdf\#page $=57$

[33] Bhat GM, Mughal AH, Malik AR, Islam MA. Chemical Science Review and Letters Developing a New Technique for Rapid Seed Extraction from the Cones of Himalayan Conifer (Pinus Wallichiana A.B. Jackson). Chem Sci Rev Lett. 2017;6(22):746-51.

[34] Ngugi MR, Mason EG, Whyte AGD. New growth models for Cupressus lusitanica and Pinus patula in Kenya. Journal of Tropical Forest Science. 2000;12(3):524-41.

[35] Raddi P, Danti R, Rocca G Della. x Cupressocyparis leylandii. In: Enzyklopädie der Holzgewächse [Internet]. 3rd ed. 2012. p. 1-17. Available from: https://onlinelibrary.wiley.com/doi/abs/10.1002/ 9783527678518.ehg2019001

[36] Aniszewska M. Changes in humidity and temperature inside the pine cones ( Pinus sylvestris L .) in two stages seed extraction. 2013;74(3):205-14.

[37] Lev-yadun S. Living serotinous cones in Cupressus sempervirens. International Journal of Plant Sciences [Internet]. 1995;156(1):50-4. Available from: https://www.jstor.org/stable/2474898?origin=JSTOR-pdf

[38] Lovreglio R, Salvatore R, Giaquinto P, Leone V. Thermal Treatments and Germination Response Over Time of Seeds From Serotinous and Non Serotinous Cones of Pinus halepensis Mill. In: International workshop MEDPINE 3: conservation, regeneration and restoration of Mediterranean pines and their ecosystems. 2007. p. 155-66.

[39] ISTA. ISTA News Bulletin: Towards automated single counts of radicle emergence to predict seed and seedling vigour. Seed Testing International. 2011;(142):44-8.

[40] E. W. Belcher J, Karrfalt RP. The processing of conifer seed. In: Small lot forest seed processing workshop [Internet]. Georgia: USDAFSASPF; 1977. p. 9-17. Available from:http://books.google usercontent.com/books/content?req=AKW5QacTE7b55aqjrUGcbS6zZDDvNRsmhe28V5jJuN_HlkX1Bn qgiSjAuUDT-7wzxoP80LLpRGQjjcxKkHWNVqao3V_6_tcgvTFl24FtoczuW7MiZ5pABTJnk_afnBt Yh5uIGN6in3YWtj5eszm8akUFdMIKPIcRFIFtGnWaKqJürcRIsJ9YAI9DEahFehrSj4_8luGt_

[41] Garcillán PP. Seed release without fire in Callitropsis guadalupensis, a serotinous cypress of a Mediterranean-climate oceanic island. Journal of Arid Environments [Internet]. 2010 Apr;74(4):512-5. Available from: https://linkinghub.elsevier.com/retrieve/pii/S0140196309002973

[42] Barbour MG. Closed-cone Pine and Cypress forests. In: Barbour MG, Keeler-Wolf T, Schoenherr AA, editors. Terrestial vegetation of California [Internet]. Third. Los Angeles: University of California Press; 2007. p. 296-312. Available from: https://www.degruyter.com/document/doi/10.1525/9780520933361013/html

[43] Milich KL. Cone serotinity and seed viability of fire-prone California Cupressus species [Internet]. Humboldt State University; 2010. Available from: https://scholarworks.calstate.edu/downloads/jq085n46h 
[44] Sfairi Y, Lahcen O, Najib M, Feddy A, Abbad A. Dormancy-breaking and salinity / water stress effects on seed germination of Atlas cypress, an endemic and threatened coniferous species in Morocco. African Journal of Biotechnology. 2012;11(19):4385-90.

[45] Porter RH. Recent developments in seed technology. The Botanical Review [Internet]. 1949;XV(5):283344. Available from: https://link.springer.com/content/pdf/10.1007/BF02861694.pdf

[46] Fierro-Cabo A, Plamann A. Enhancing the seed germination process of Montezuma cypress (Taxodium mucronatum Ten.). Journal of Forest Research [Internet]. 2021;26(1):81-5. Available from: https://doi.org/10.1080/13416979.2020.1845422

[47] Hossain MA, Islam KS, Rajasree N, Hossain MK, Alam MS. Pre-sowing treatments for improved germination and growth of two rare native species of Bangladesh. Journal of Forestry Research [Internet]. 2018;29(5):1277-82. Available from: https://doi.org/10.1007/s11676-017-0554-9

[48] Bonner FT. Storage of seeds: Potential and limitations for germplasm conservation. Forest Ecology and Management. 1990;35(1-2):35-43.

[49] Goggans JE, Jones L, Lynch DK. Germination rate of Arizona Cypress improved by better cone collection techniques and seed pregermination treatments. [Internet]. Vol. 25, Tree planters' notes. 1974 [cited 2021 Jul 19]. p. 3-4. Available from: https://www.cabdirect.org/cabdirect/abstract/19740617242

Citation: Alice Adongo Onyango et al. "Variations in Cupressus lusitanica Mill. Seed Yield and Quality under Different Extraction Conditions in Kenya” International Journal of Forestry and Horticulture (IJFH), vol 7, no. 1, 2021, pp. 1-10. doi: http://dx.doi.org/10.20431/2454-9487. 0701001.

Copyright: (C) 2021 Authors. This is an open-access article distributed under the terms of the Creative Commons Attribution License, which permits unrestricted use, distribution, and reproduction in any medium, provided the original author and source are credited. 